\title{
Napovedi sprememb rabe tal v Sloveniji do leta 2012
}

\author{
Franci Petek \\ Geografski inštitut Antona Melika, Znanstvenoraziskovalni center SAZU, \\ Gosposka 13, 1000 Ljubljana, Slovenija \\ e-mail: petek@zrc-sazu.si
}

\section{Izvleček}

Po podatkih iz zemljiškega katastra smo izdelali analizo sprememb rabe tal med letoma 1994 in 1999. Ta je bila osnova za napoved sprememb rabe tal do leta 2012. $\mathrm{Na}$ podlagi linearnega trenda sprememb deležev površin do leta 2012 smo prikazali napovedi sprememb deležev površine za osnovne zemljiške kategorije. Najbolj naj bi se zmanjšal delež sadovnjakov, povečal pa delež pozidanih površin.

Ključne besede: spremembe rabe tal, napovedi, Slovenija

\section{Anticipated Changes In Land Use In Slovenia Until 2012}

\begin{abstract}
Using data from the land cadastre, we undertook an analysis of changes in land use between 1994 and 1999 and used the results to forecast changes in land use until 2012. On the basis of the linear trend of changes in the proportions of areas until 2012, we showed anticipated changes in proportions of areas according to basic land categories. The proportion of orchard should decrease the least, while the proportion of built-up area should increase the most.
\end{abstract}

Key words: land use changes, anticipations, Slovenia 


\section{UVOD}

Spremembe rabe tal so dinamičen proces v prostoru in odsevajo človekovo delovanje skozi čas. V Sloveniji se delež gozda $\mathrm{v}$ zadnjih stotih letih stalno povečuje, obdelovanih zemljišč pa v večini zmanjšuje. Vse bolj pomemben delež površine predstavlja urbanizacija, ki svoj novi prostor skoraj praviloma išče $\mathrm{v}$ dolinskem oziroma ravninskem svetu.

Rezultate in metode sprememb rabe zemljišč se s pridom lahko uporabi tudi za aplikativne naloge. Ministrstvo za okolje, prostor in energijo je v Poročilo o stanju okolja želelo vključiti karto napovedi sprememb površine travinj (travniki in pašniki) leta 2006 in leta 2012. Sodelavci Geografskega inštituta Antona Melika ZRC SAZU smo jih izdelali na podlagi rezultatov o spremembi rabe tal med letoma 1994 in 1999 po podatkih iz zemljiškega katastra (1994; 1999) v slovenskih pokrajinah (Gabrovec et al 1998). Ugotovili smo, da naj bi se površina travinj različno spremenila $\mathrm{v}$ različnih slovenskih pokrajinah. Za ta prispevek smo izračunali linearni trend sprememb deležev površin do leta 2012 tudi za ostale osnovne zemljiške kategorije. Najbolj naj bi se zmanjšal delež sadovnjakov, povečal pa delež pozidanih površin.

\section{VIRI PODATKOV IN METODOLOŠKA IZHODIŠČA}

$\mathrm{S}$ preučevanjem rabe in sprememb rabe tal ter njihove povezanosti z drugimi dejavniki in procesi v prostoru se je ukvarjalo več slovenskih geografov. Med analizami sprememb rabe tal za območje celotne Slovenije gre izpostaviti dela Medveda (1970), Gabrovca in Kladnika (1997) ter slednjih dveh avtorjev in Petka (2001). Vsa omenjena dela preučujejo spremembe rabe tal po enotni metodologiji na podlagi podatkov o površini zemljiških kategorij iz zemljiškega katastra, združenih na ravni katastrskih občin, vendar za različna časovna obdobja. Prav podatki o površinah osnovnih zemljiških kategorij iz zemljiškega katastra za različna leta, so bili podlaga za ta prispevek. Kljub dejstvu, da so podatki o rabi iz zemljiškega katastra vsaj od leta 1974 naprej v stalnem zaostanku za dejansko rabo (Demšar 1996), je prednost izbire teh podatkov enotna metodologija zajemanja podatkov za primerjana leta. Uporabili smo podatke za leto 1896 (Leksikon občin 1906), 1951, 1953, 1961, 1971, 1979, 1994 in 1999 (Zemljiški kataster). Podatki o rabi tal za omenjena leta so bili že pripravljeni in usklajeni na raven katastrskih občin za potrebe omenjenih treh študij, zato izbor let zajema podatkov ni periodičen. V analizi smo upoštevali naslednje zemljiške kategorije: njive z vrtovi, sadovnjake, vinograde, travnike, 
pašnike, gozdove, trstičja (močvirja) in ostalo (pozidano, prometnice, neplodno, vode).

Ker je naročnik študije (Ministrstvo za okolje, prostor in energijo) želel rezultate o napovedi sprememb na večji prostorski enoti kot je katastrska občina, smo podatke o površinah zemljiških kategorij po katastrskih občinah $\mathrm{v}$ dogovoru z naročnikom združili na raven slovenskih naravnogeografskih pokrajin, ki jih je omejila skupina znanstvenikov na Geografskem inštitutu Antona Melika ZRC SAZU (Gabrovec et al, 1998). Ta regionalizacija loči 4 makroregije (Alpski, Dinarski, Panonski in Sredozemski svet), 9 submakroregij in 48 mezoregij ali pokrajin (preglednica 1). Mejne katastrske občine med dvema ali več pokrajin, smo v celoti uvrstili v eno izmed pokrajin. Kriterij za uvrstitev mejne katastrske občine $\mathrm{v}$ določeno pokrajino, je bil prevladujoč delež površine v njej. Zato so skupne površine in obsegi pokrajin različni od dejanskih, kar v kartografskem prikazu rezultatov nismo upoštevali.

\subsection{Metodološka izhodišča in pojasnila}

Napovedi sprememb rabe tal do leta 2012 smo računali na osnovi linearnega trenda sprememb deležev površin za vsako od osnovnih zemljiških kategorij. Desetletno obdobje naj bi bilo še dovolj blizu sedanjemu stanju, da so napovedi kolikor toliko realne. Kot trend sprememb smo vzeli povprečno letno stopnjo rasti ali upada deleža vsake zemljiške kategorije med letoma 1994 in 1999. Kljub temu, da gre za projekcijo sprememb rabe tal v razmeroma kratkem časovnem obdobju, menimo, da se $\mathrm{v}$ tem obdobju najbolj pravilno odsevajo spremembe v Sloveniji po letu 1991. Izhodiščno stanje za napovedi sprememb deležev zemljiških kategorij leta 2012 je bilo iz leta 1999, katerega smo pomnožili z letno stopnjo sprememb med letoma 1994 in 1999 na število let (v našem primeru 7 in 13).

Kartografsko smo prostorsko razporeditev napovedi sprememb leta 2012 $\mathrm{v}$ deležih prikazali le za njive, travnike, pašnike ter gozdove in sicer na ravni zgoraj omenjenih pokrajin. Večanje deležev smo prikazali z različno gostoto diagonalnih črt, manjšanje $\mathrm{z}$ različno gostoto navpičnih črt. Velikosti sprememb za njive, travnike in pašnike smo združili v razrede po $5 \%$, za gozdove pa $\mathrm{v}$ razrede po $0,5 \%$ oziroma $1 \%$.

Prikazali smo tudi letne stopnje sprememb deležev vseh osnovnih zemljiških kategorij na ravni celotne Slovenije. Računali smo letne stopnje med letoma 1896 in 1953, 1953 in 1961, 1961 in 1971, 1971 in 1979, 1979 in 1994 ter kot že rečeno med letoma1994 in 1999. Pri slednjem prikazu je treba upoštevati, da so pri podatkih o deležih površin za leto 1896 sadovnjaki sešteti s travniki, za leto 1953 pa le pri nekaterih katastrskih občinah. Zato je letna stopnja 
sprememb na ravni Slovenije za travnike in sadovnjake popolnoma pravilna šele od primerjave med letoma 1961 in 1971 naprej.

\section{REZULTATI}

Najprej smo obdelali spremembe rabe zemljišč, trende in na podlagi njih napovedi za celotno Slovenijo. V naslednjih podpoglavjih pa še napovedi sprememb za najpomembnejše zemljiške kategorije po slovenskih pokrajinah, ki smo jih prikazali tudi kartografsko.

\subsection{Napovedi sprememb za celotno Slovenijo Slovenija}

Preprosta primerjava deležev osnovnih zemljiških kategorij med letoma 1896 in 1999 nam pokaže, da se je obseg obdelovalnih zemljišč, z izjemo travnikov, zmanjšal, prav tako pašnikov in trstičja, zvečal pa se je obseg gozdov in pozidanih zemljišč (kategorija ostalo). V približno stoletnem obdobju se je relativno najbolj zmanjšala površina vinogradov. Kar za dobrih $50 \%$, in sicer iz 2,25 \% celotne površine Slovenije leta 1896 na 1,07 \% leta 1999. Najbolj se je povečal delež pozidanih zemljišč, prav tako za $50 \%$ z $5 \%$ na $7,55 \%$. Podrobneje lahko vidimo gibanje deležev osnovnih zemljiških kategorij med letoma 1896 in $1999 \mathrm{v}$ preglednici 2 in na grafikonu 1 . Travnike in sadovnjake smo za pravilnejšo predstavo še sešteli in $\mathrm{v}$ preglednici ter grafikonu prikazali kot posebno kategorijo.

Preglednica 1: Deleži površin osnovnih zemljiških kateg. med l. 1896 in 1999.

\begin{tabular}{|l|c|c|c|c|c|c|c|c|c|c|}
\hline leto & njive & travn. & sado. & vinog. & pašn. & gozd. & trsti. & ostalo & Slov. & tr+sad \\
\hline 1896 & 18,61 & 16,75 & 0,00 & 2,25 & 16,50 & 40,88 & 0,00 & 5,00 & 100,0 & 16,75 \\
\hline 1953 & 17,75 & 17,29 & 0,76 & 1,58 & 14,97 & 42,16 & 0,09 & 5,40 & 100,0 & 18,05 \\
\hline 1961 & 15,48 & 18,03 & 1,72 & 1,23 & 14,21 & 43,56 & 0,09 & 5,70 & 100,0 & 19,75 \\
\hline 1971 & 14,09 & 18,73 & 2,02 & 1,09 & 12,22 & 45,81 & 0,08 & 5,97 & 100,0 & 20,75 \\
\hline 1979 & 13,36 & 19,10 & 2,09 & 1,08 & 11,10 & 47,05 & 0,08 & 6,14 & 100,0 & 21,19 \\
\hline 1994 & 12,61 & 18,09 & 1,97 & 1,06 & 10,23 & 48,85 & 0,07 & 7,12 & 100,0 & 20,06 \\
\hline 1999 & 12,45 & 17,79 & 1,88 & 1,07 & 10,28 & 48,92 & 0,06 & 7,55 & 100,0 & 19,68 \\
\hline $\begin{array}{l}1999-1896 \\
\text { v\% točkah }\end{array}$ & $-6,16$ & 1,04 & 1,88 & $-1,18$ & $-6,22$ & 8,05 & 0,06 & 2,54 & & 2,92 \\
\hline $\begin{array}{l}\text { indeks } \\
1896-1999\end{array}$ & 67,0 & 98,7 & 109,7 & 47,5 & 62,3 & 119,7 & 62,7 & 150,9 & & 117,4 \\
\hline
\end{tabular}

Vir: Leksikon občin 1906; Zemljiški kataster 1953, 1961, 1971, 1979, 1994, 1999. 
Grafikon 1: Deleži površin osnovnih zemljiških kategorij med letoma 1896 in 1999 ter napoved deležev površin za leto 2012.

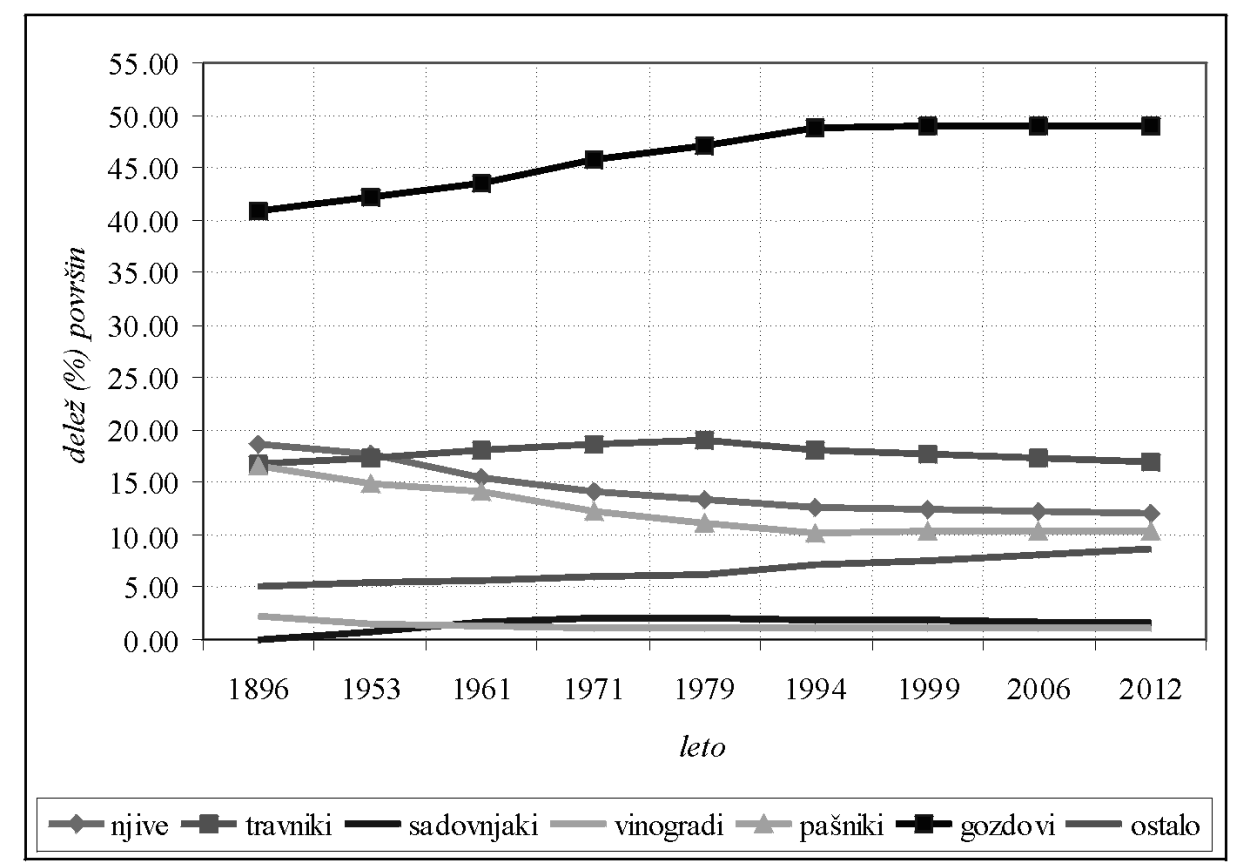

Vir: Leksikon občin 1906; Zemljiški kataster 1953, 1961, 1971, 1979, 1994, 1999.

Iz grafikona 1 vidimo, da se upad obdelovalnih zemljišč $\mathrm{v}$ zadnjih petih letih umirja, prav tako porast gozdov. Izjema so pozidana zemljišča (kategorija ostalo), ki vidnejše naraščajo šele po letu 1979.

Za še bolj pregledno predstavo sprememb osnovnih zemljiških kategorij med letoma 1896 in 1999 smo jih na ravni celotne Slovenije prikazali še s povprečno letno rastjo $\mathrm{v}$ šestih zaporednih časovnih obdobjih.

Grafikon 2 nam kaže, da je bil največji povprečni letni upad deleža površine njiv med letoma 1953 in 1961, ko je znašal 1,7 \% letno. Kasneje se je povprečni letni delež upada stalno zmanjševal in je $\mathrm{v}$ zadnjem primerjanem obdobju znašal le še $0,26 \%$.

Drugače je pri travnikih. Še v obdobju 1971-1979 je bila povprečna letna sprememba pozitivna, po letu 1979 pa negativna in je v obdobju 1994-1999 znašala $-0,33 \%$ deleža površine letno. To pomeni, da se je delež površine travnikov v tem obdobju hitreje zmanjševal kot delež površine njiv.

Še bolj radikalen obrat kot pri travnikih smo ugotovili pri sadovnjakih. V obdobju 1961-1971 se je letno delež površine v povprečju povečal skoraj za 
$2 \%$, med letoma 1979 in 1994 je bila ta vrednost že negativna, v zadnjem primerjanem obdobju pa je bil povprečni letni delež spremembe površine sadovnjakov med obdelovalnimi zemljišči sploh največji in je znašal skoraj $1 \%$ letno.

Grafikon 2: Povprečna letna stopnja sprememb površine osnovnih zemljiških kategorij v deležih na ravni celotne Slovenije.

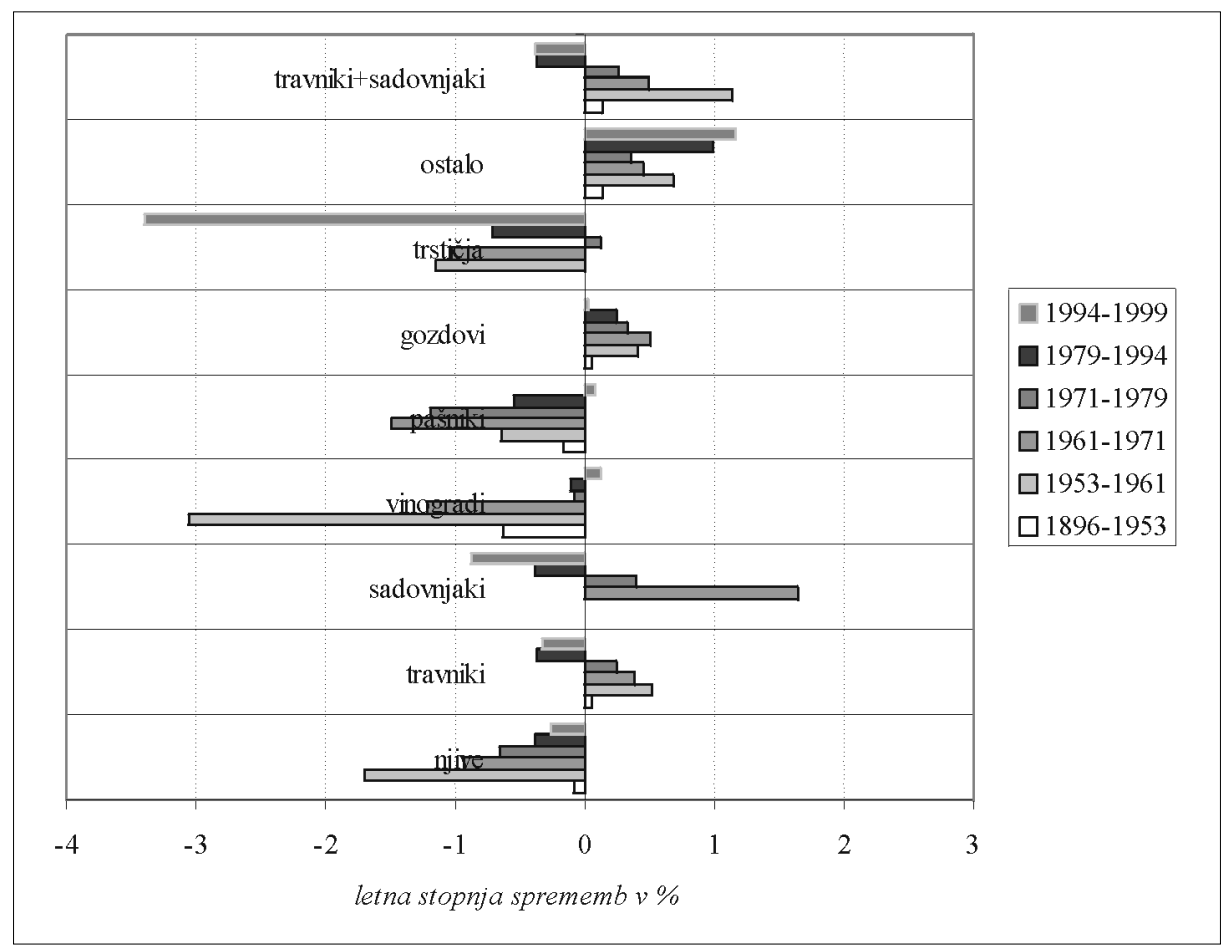

Vir: Leksikon občin 1906; Zemljiški kataster 1953, 1961, 1971, 1979, 1994, 1999.

Vinogradi so se najbolj zmanjševali med letoma 1953 in 1961, letno za več kot $3 \%$ od deleža celotne površine. V tem obdobju se je najbolj povečeval delež travnikov in sadovnjakov skupaj. Po letu 1971 se je upad močno zmanjšal, med letoma 1994 in 1999 pa je bila povprečna letna sprememba deleža površine vinogradov celo pozitivna, znašala je $0,13 \%$ na leto.

Višek upada deleža površine pašnikov smo ugotovili med letoma 1961 in 1971, ko je v povprečju znašal 1,5\% letno. Po letu 1971 se je povprečni letni upad hitro zmanjševal, med letoma 1994 in 1999 pa je bila povprečna letna sprememba že pozitivna in je znašala $0,08 \%$. 
Samo gozdovi in pozidana zemljišča so imela $\mathrm{v}$ vseh primerjanih obdobjih pozitivno povprečno letno spremembo. Gozdovi so se v povprečju na leto najbolj povečali med letoma 1961 in 1971, to je v obdobju, ko se je najbolj zmanjševal delež površine pašnikov. Po letu 1971 se je povprečna letna rast deleža površine gozdov zmanjševala in je v obdobju 1994-1999 znašala le $0,03 \%$ letno.

Delež površine pozidanih zemljišč (kategorija ostalo) se med vsemi osnovnimi zemljiškimi kategorijami najbolj povečuje. Že med letoma 1979 in 1994 se je v povprečju povečal za 1 \% letno, med letoma 1994 in 1999 celo že več kot za odstotek.

S tem, ko smo izračunali povprečne letne spremembe osnovnih zemljiških kategorij, smo dobili osnovo za računanje trenda sprememb v prihodnosti in ga na ravni Slovenije prikazali na grafikonu 1. Od leta 1999 do leta 2012 naj bi se delež površine njiv vsako leto zmanjšal za $0,26 \%$, travnikov za $0,33 \%$, sadovnjakov $0,88 \%$ in trstičja za $3,4 \%$. Delež površine vinogradov naj bi se povečal $0,13 \%$, pašnikov $0,08 \%$, gozdov $0,03 \%$ in pozidanih zemljišč kar za $1,16 \%$. Te vrednosti se morda zdijo zanemarljive, vendar če končne deleže površin osnovnih zemljiških kategorij prevedemo $\mathrm{v}$ absolutne vrednosti (hektari), je predstava o dejanskih spremembah bolj jasna (preglednica 3). Ob upoštevanju trenda sprememb med letoma 1994 in 1999 naj bi bilo leta 2012 v Sloveniji za 8719 hektarov manj njiv, travnikov celo za 15724 hektarov kot 13 let prej. Zanemarljiv ni niti upad trstičij (kamor spadajo močvirja, barja in podobno), čeprav naj bi se njihova površina zmanjšala »zgolj« za 434 hektarov. Na drugi strani naj bi se površina pozidanih zemljišč povečala kar za 24492 hektarov.

Preglednica 2: Razlika absolutnih vrednosti (hektari) površin osnovnih zemljiških kategorij med letom 1999, 2006 in 2012.

\begin{tabular}{|l|r|r|r|r|r|r|r|r|r|}
\hline Leto & njive & travn. & sadov. & vinog. & pašn. & gozd. & trstič. & ostalo & Slov. \\
\hline 1999 & 252132 & 360443 & 38146 & 21687 & 208153 & 991027 & 1194 & 152838 & 2025621 \\
\hline 2006 & 247481 & 352005 & 35837 & 21865 & 209224 & 992643 & 937 & 165628 & 2025621 \\
\hline 2012 & 243413 & 344719 & 33949 & 22006 & 210018 & 993423 & 760 & 177330 & 2025621 \\
\hline $\begin{array}{l}2006- \\
1999\end{array}$ & -4652 & -8438 & -2309 & 179 & 1071 & 1616 & -257 & 12789 & 0 \\
\hline $\begin{array}{l}2012- \\
1999\end{array}$ & -8719 & -15724 & -4197 & 320 & 1865 & 2397 & -434 & 24492 & 0 \\
\hline
\end{tabular}




\subsection{Napovedi po slovenskih pokrajinah}

$\mathrm{Na}$ ravni 48 slovenskih pokrajin smo kartografsko prikazali spremembe deležev površin le za njive, travnike, pašnike in gozdove.

\subsubsection{Njive}

Na zemljevidu 2 vidimo, da naj bi se delež njiv povečal le $\mathrm{v}$ sedmih pokrajinah, in sicer, z izjemo Vipavske doline, le na vzhodu Slovenije. Najbolj v Dravinjskih goricah, za dobrih $10 \%$. Delež njiv naj bi se najbolj zmanjšal v alpskih pokrajinah. Za več kot $15 \%$ v Julijskih Alpah, Kamniško-Savinjskih Alpah, na Strojni, Kozjaku in Pohorju ter v Vzhodnih Karavankah, kjer naj bi se zmanjšale najbolj, kar za 34 \% (glej zemljevid 2).

\subsubsection{Travniki}

Podobno kot pri njivah, naj bi se delež površine travnikov povečal le v desetih pokrajinah. Na zemljevidu 3 vidimo, da so te pokrajine nekako združene $\mathrm{v}$ dveh otokih: na severu Slovenije proti vzhodu ter tri dinarske pokrajine v osrednji Sloveniji, med njimi tudi Raduljsku hribovje, kjer naj bi se delež površine travniki povečal najbolj, za $8 \%$. Delež površine travnikov naj bi se najbolj zmanjšal v Dravinjskih goricah za $19 \%$ in v Vipavski dolini za dobrih $15 \%$.

\subsubsection{Pašniki}

Presenetljiva je ugotovitev, da naj bi se delež površine pašnikov zmanjšal v manj kot polovici vseh pokrajin. Na zemljevidu 4 izstopajo pokrajine na severovzhodu Slovenije, kjer naj bi se delež površine pašnikov zmanjšal vsaj za $5 \%$, še posebej pa Savska ravan z Ljubljanskim barjem, kjer naj bi se delež površine pašnikov najbolj zmanjšal, in sicer za $24 \%$.

Med pokrajinami, kjer naj bi se delež površine pašnikov povečal, izstopa pas pokrajin od severa Slovenije proti Halozam. V slednji pokrajini ter v Velenjskem in Konjiškem hribovju naj bi se povečal za $13 \%$, kar je med vsemi pokrajinami največ.

\subsubsection{Gozdovi}

V splošnem naj bi se delež površine gozdov povečal v pokrajinah na zahodu Slovenije, zmanjšal pa na vzhodu. Vendar pa so pokrajine, v katerih naj bi se delež povečal za več kot $2 \%$ razpršene po celi Slovenije: od Murske ravani, Suhe krajine, Ribniško-Kočevskega podolja do Julijskih Alp. Podobno je s pokrajinami, v katerih naj bi se delež površine gozdov najbolj zmanjšal: razpršene so od Vipavske doline do Dravske ravani. 
Zemljevid 1: Napovedi sprememb deležev njiv v slovenskih pokrajinah od leta 1999 do 2012 v deležih.

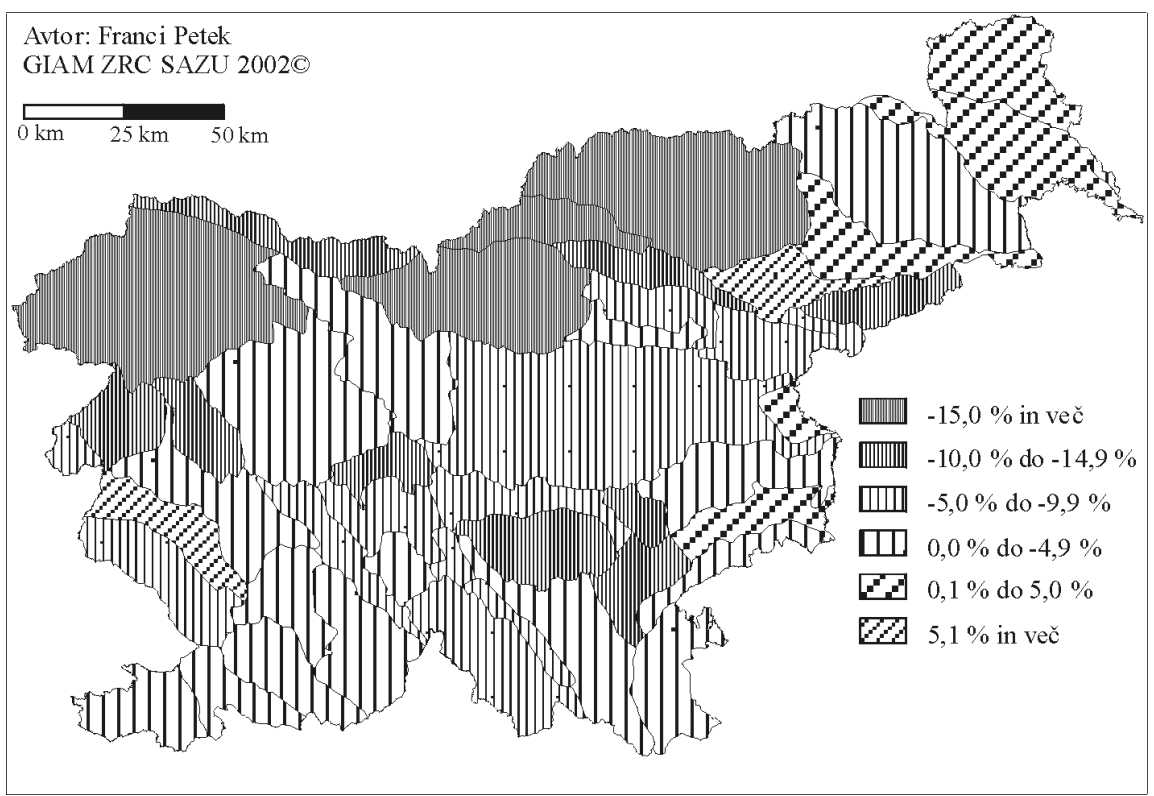

Zemljevid 2: Napovedi sprememb deležev travnikov v slovenskih pokrajinah od leta 1999 do 2012 v deležih.

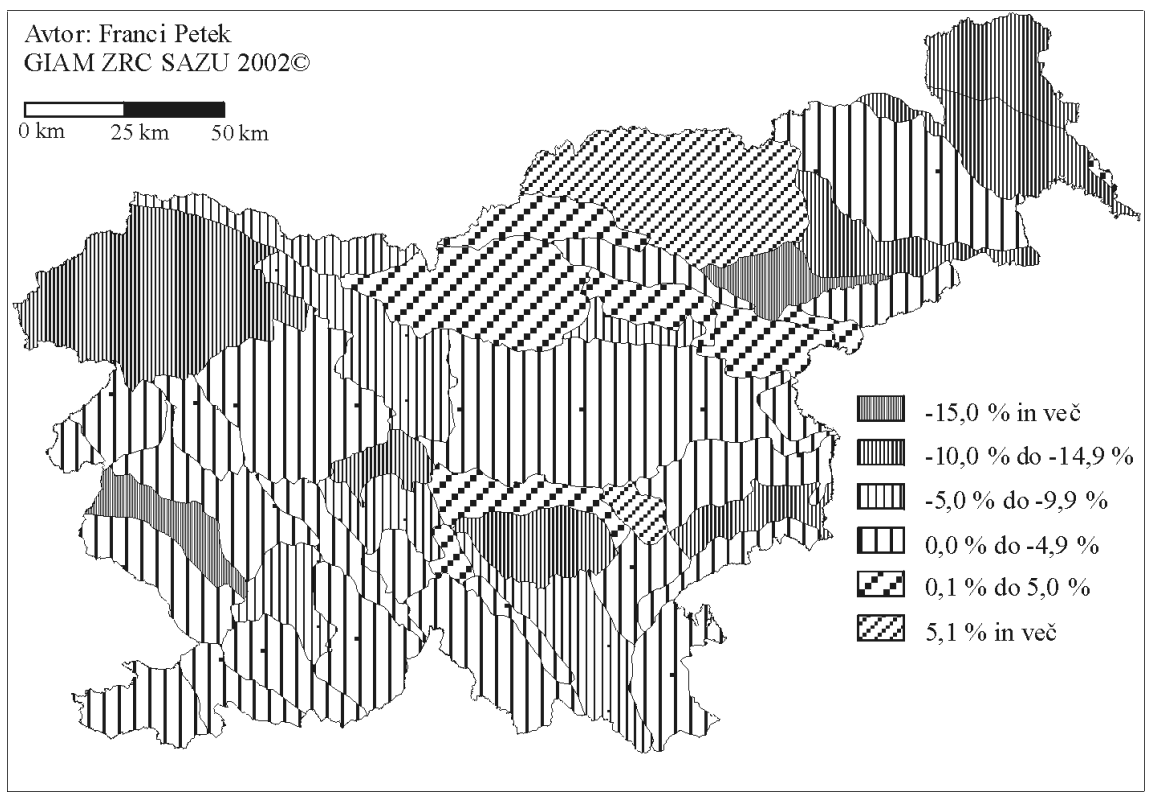


Zemljevid 3: Napovedi sprememb deležev pašnikov v slovenskih pokrajinah od leta 1999 do 2012 v odstotkih.

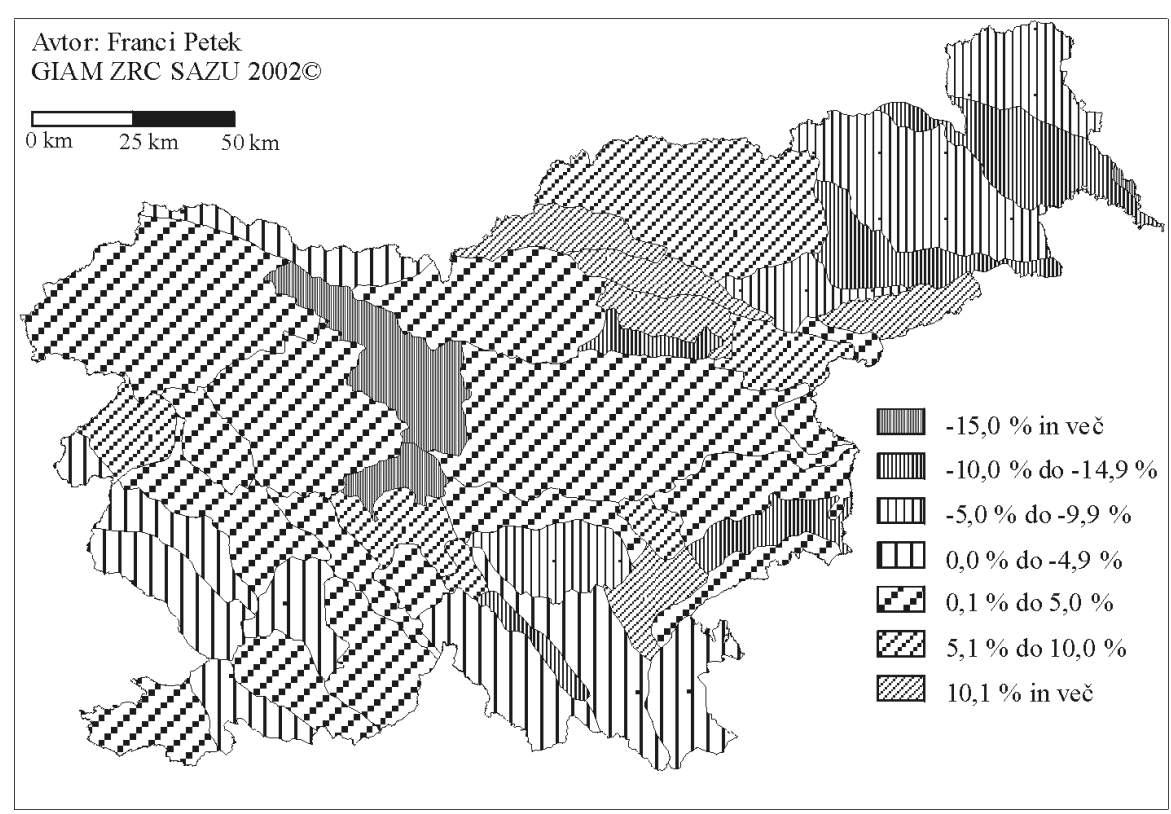

Zemljevid 4: Napovedi sprememb deležev gozdov v slovenskih pokrajinah od leta 1999 do 2012 v odstotkih.

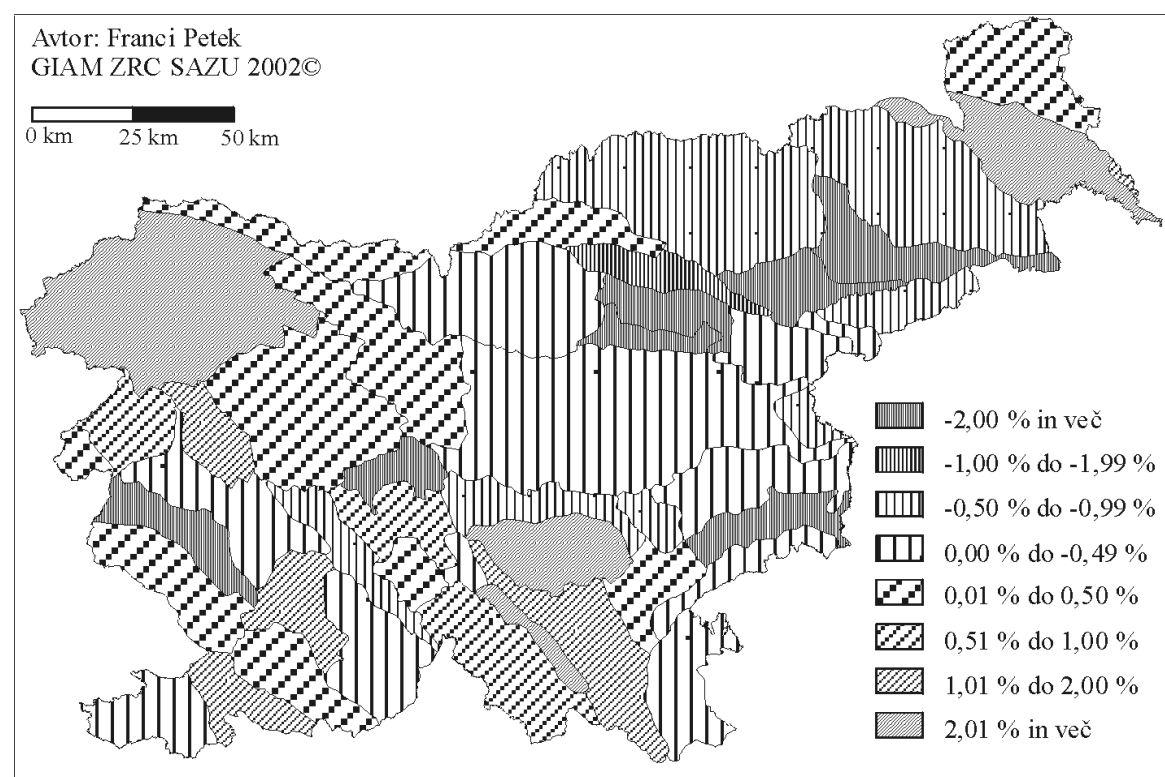




\section{SKLEP}

Kritična presoja zgornjih rezultatov napovedi sprememb rabe tal, je še enkrat potrdila slabo kakovost oziroma zaostajanje za dejanskim stanjem podatkov o rabi tal iz zemljiškega katastra. Zagotovo sicer držijo ugotovitve, da se bo delež večine kmetijskih zemljiški kategorij še naprej zmanjševal, delež gozda in pozidanih zemljišč pa povečeval. Po naši presoji, ki temelji na poznavanju dejanskih razmerij in sprememb zemljiških kategorij rabe tal iz terenskega dela na posameznih območjih Slovenije, pa ugotovljeni rezultati kažejo premajhno rast deleža površine gozdov ter preveliko rast deleža površine pozidanih zemljišč v primerjavi s spremembami ostalih zemljiških kategorij. Po ocenah gozdarjev delež gozdov danes že močno presega polovico Slovenije, temu primerno bi bil tudi trend sprememb do leta 2012 drugačen. Pri pozidanih zemljiščih je potrebno upoštevati dejstvo, da se spremembe za to zemljiško kategorijo najbolj ažurno vpisujejo $\mathrm{v}$ zemljiškem katastru in je zato izračunani trend sprememb med letoma 1994 in 1999 med vsemi zemljiškimi kategorijami najbolj pravilen. Pričakovati pa je, da bo po izgraditvi avtocestnega križa delež pozidanih zemljišč počasneje naraščal, česar pa $v$ študiji nismo upoštevali. Temu primerno so tudi napovedi sprememb ostalih zemljiških kategorij nekoliko izkrivljene. Vseeno pa so izračunane napovedi sprememb rabe tal do leta 2012, vsaj groba ocena kakšno naj bi bilo razmerje zemljiških kategorij rabe tal čez deset let. Zanimive so ugotovitve, da naj bi se delež njiv, kljub splošnemu upadu, predvsem v nekaterih pokrajinah severovzhodne Slovenije vseeno povečal. Presenetljiva je ugotovitev, da naj bi se delež travnikov povečal le v desetih pokrajinah, na drugi strani pa naj bi delež pašnikov povečal v več kot polovici od 48 pokrajin.

\section{Literatura in viri:}

Demšar, B., 1996, Zemljiški kataster v Sloveniji - stanje in perspektive. V: Zgodovina (2.del) - stanje in perspektive slovenske geodezije in geofizike, GURS, Ljubljana.

Gabrovec, M., Kladnik, D., Orožen Adamič, M., Pavšek, M., Perko, D., Topole, M., 1998, Pokrajine v Sloveniji. V: Perko, D., Orožen Adamič, M. (urednika), Slovenija pokrajine in ljudje, Ljubljana, Založba Mladinska knjiga, 28-29.

Gabrovec, M., Kladnik, D., Petek, F., 2001. Land Use Changes in $20^{\text {th }}$ Century in Slovenia. V: Himiyama, J., Mather, A., Bicik, I., Milanova, E. V. (uredniki), Land Use/Cover Changes in Selected Regions in the World, Volume I, IGU-LUCC, Asahikawa, 41-52. 
Gabrovec, M., Kladnik, D., 1997. Some new aspects of land use in Slovenija. Geografski zbornik, 37, 7-64.

Leksikon občin 1906 kraljestev in dežel zastopanih v državnem zboru, Izdelan po popisu prebivalstva dne 31. grudna 1900. 4 knjige, Dunaj.

Medved, J., 1970. Spremembe v izrabi zemljišča in preslojevanja kmečkega prebivalstva v Sloveniji v zadnjih desetletjih. Geografski vestnik, 42, 3-30.

Zemljiški kataster 1951, GURS, Ljubljana.

Zemljiški kataster 1953, GURS, Ljubljana.

Zemljiški kataster 1961, GURS, Ljubljana.

Zemljiški kataster 1971, GURS, Ljubljana.

Zemljiški kataster 1979, GURS, Ljubljana.

Zemljiški kataster 1994, GURS, Ljubljana.

Zemljiški kataster 1999, GURS, Ljubljana.

\title{
ANTICIPATED CHANGES IN LAND USE IN SLOVENIA UNTIL 2012
}

\begin{abstract}
Summary
Using data from the land cadastre, we undertook an analysis of changes in land use between 1994 and 1999 and used the results to forecast changes in land use until 2012 in Slovenia and in forty-eight natural geographical Slovene regions (Gabrovec et al 1998). On the basis of the linear trend of changes in the proportions of areas until 2012, we showed anticipated changes in proportions of areas according to basic land categories (fields, meadows, orchards, vineyards, pastures, forests, and other). The proportion of orchard should decrease the least, while the proportion of built-up area should increase the most.

We also present the changes in land use in Slovenia generally between 1896 and 1953, 1953 and 1961, 1961 and 1971, 1971 and 1979, 1979 and 1994, and 1994 and 1999. Graph 1 shows the changes in the proportions of land category areas between 1896 and 1999 in a simple manner, while a more detailed presentation of the changes in basic land categories between 1896 and 1999 for Slovenia overall is shown on Graph 2 with the average annual increase in the proportions of areas in six consecutive time periods. The fall in the proportion of cultivated field areas decreases constantly, as does the proportion of vineyards, which have recently been increasing. The proportion of meadow increases until 1979, after which it decreases. The same pattern of average annual change was determined for orchards. The proportion of pastures has recently increased, somewhat surprisingly since previously this cate-
\end{abstract}


gory was constantly decreasing. The increase in proportion of forest is stable, unlike the increase in the proportion of built-up area, which is rising rapidly. From these findings and trends, we calculated probable changes in the proportions of basic land categories until 2012. The absolute values of changes in hectares are shown in Table 3.

At the level of forty-eight natural geographical regions we cartographically present the anticipated changes in the proportions of areas of cultivated field, meadow, pasture, and forest in percent. On each map, diagonal lines of different density show regions where changes in the proportion of the illustrated land category will be positive by 2012 , vertical lines of different density show those regions where they will be negative. Map 1, for example, shows the anticipated changes in cultivated field areas, which should be positive primarily in regions of eastern Slovenia. A positive change in the proportion of meadows will only occur in ten regions, mainly in Alpine and Dinaric regions (map 2). A surprising discovery is that the proportion of pasture areas will decrease in fewer than half of all the regions. A belt of regions from the eastern Alps to the central Pannonian hills stands out among the regions where the proportion of pastureland will increase the most (map 3). The proportion of forest will generally increase in western Slovenia and decrease in the east (map 4).

Critically examining the results, we determined that they show too small an increase in the proportion of forest and too large an increase in the proportion of built-up areas. The reason for this is the poor quality of information regarding land use in the land cadastre, which has been constantly in arrears since 1974 at least. Although the results acquired are therefore partly distorted, they nevertheless generally reflect the basic trend of changes in land use in Slovenia: the proportion of mostly farmland category areas will continually decrease while forest areas and built-up areas will increase. An interesting discovery is that while the proportion of cultivated field is generally decreasing, it will increase in some northeastern regions of Slovenia. It is surprising that the proportion of meadow will increase in only ten regions while on the other hand the proportion of pasture will increase in more than half of the forty-eight regions. 